\title{
Eating Habits among Lithiasic Patients in Kinshasa, the Democratic Republic of Congo
}

\author{
Pablo Kuntima Diasiama Diangienda ${ }^{{ }^{*}}{ }^{\mathbb{D}}$, Dieudonné Molamba Moningo1, \\ Alain Ngoma Mayindu², Jean-Robert Rissasy Makulo ${ }^{3}$, Ernest Kiswaya Sumaili ${ }^{3}$, \\ Eric Musalu Mafuta4, Mathieu Nkumu Loposso', Augustin M. L. Punga-Maole1, \\ Simon Lwa Nkandi Lufuma', Jean-Philippe Haymann' ${ }^{5}$, Michel Daudon ${ }^{5}$ \\ ${ }^{1}$ Department of Urology, University Hospital of Kinshasa, Kinshasa, Democratic Republic of Congo \\ ${ }^{2}$ Department of Clinical Biology, University Hospital of Kinshasa, Kinshasa, Democratic Republic of Congo \\ ${ }^{3}$ Department of Nephrology, University Hospital of Kinshasa, Kinshasa, Democratic Republic of Congo \\ ${ }^{4}$ School of Public Health, University of Kinshasa, Kinshasa, Democratic Republic of Congo \\ ${ }^{5}$ Department of Functional Investigations, Tenon Hospital, Paris, France \\ Email: *pablodiang@gmail.com
}

How to cite this paper: Diangienda, P.K.D., Moningo, D.M., Mayindu, A.N., Makulo, J.-R.R., Sumaili, E.K., Mafuta, E.M., Loposso, M.N., Punga-Maole, A.M.L., Lufuma, S.L.N., Haymann, J.-P. and Daudon, M. (2021) Eating Habits among Lithiasic Patients in Kinshasa, the Democratic Republic of Congo. Open Journal of Urol$o g y, 11,200-213$.

https://doi.org/10.4236/oju.2021.116018

Received: April 25, 2021

Accepted: June 13, 2021

Published: June 16, 2021

Copyright () 2021 by author(s) and Scientific Research Publishing Inc. This work is licensed under the Creative Commons Attribution International License (CC BY 4.0).

http://creativecommons.org/licenses/by/4.0/

(c) (i) Open Access

\begin{abstract}
Introduction: Worldwide, the incidence of kidney stones has been progressively increasing. Various factors can influence the risk of stone formation, including lifestyle and eating habits. The dietary investigation is a standard of care in patients with urolithiasis. The objectives of this study were to determine the dietary habits of lithiasis patients in the city of Kinshasa and to investigate the association between dietary habits and the composition of the stones. Material and Methods. From January 2017 to September 2019, 85 patients attending 8 hospitals participated in the nutrition survey. Various foods commonly consumed in the Democratic Republic of Congo were categorized based on their composition: foods rich in animal proteins, foods rich in calcium, foods high in sugar, foods high in oxalate, and various vegetables and fruits. We also investigated daily water intake. The composition of the collected stones was analyzed by infrared spectrophotometry. Results. The mean (SD) age of patients was 47.1 (14.0) years, $63.5 \%$ of patients were males, $75.3 \%$ of the patients had stones located in the upper urinary tract, and $7.1 \%$ were undernourished. Most of patients consumed vegetables (77.6\%), animal proteins $(62.4 \%)$, and foods rich in oxalate (58.8\%). The daily water intake was less than $1500 \mathrm{~mL}$ in more than half of the patients (68.2\%). Major anhydrous uric acid stones were associated with a high body mass index $(\mathrm{p}=0.025)$. Male patients with a high oxalate diet had more calcium oxalate stones $(64.3 \%)$ compared to other types of stones $(\mathrm{p}=0.041)$. Conclusion: High consumptions of vegetables and low water intake were linked to the formation of cal-
\end{abstract}


cium oxalate monohydrate stones. More data are needed to confirm these findings.

\section{Keywords}

Urolithiasis, Dietary Abnormality, Insufficient Diuresis, Chemical

Composition

\section{Introduction}

Urolithiasis is a common health problem with a multifactorial etiology arising from the interaction of various factors including metabolic, genetic, and environmental [1]. Calcium oxalate accounts for the majority of kidney stones [2]. Over the last decades, urolithiasis incidence has been increasing worldwide at an alarming rate [3]. Several factors such as age, gender, race, nutrition, daily water intake, climate, geography, physical activity and Body Mass Index (BMI) play a key role in urolithiasis pathogenesis [4]. Early studies showed that nutrition contributes substantively to kidney stone formation [5] [6]. Prior evidence reported that high dietary calorie, animal protein and oxalate intake and low daily water intake, calcium and potassium consumption correlated with higher incidence of calcium oxalate stone formation, thus representing important risk factors in kidney stone formation [7] [8]. Therefore, dietary investigation represents an important step in the etiological investigation of urolithiasis [9]. Despite a wealth of studies investigating the association between kidney stone formation and nutrition habits, data on the nutritional status and dietary habits of patients afflicted with kidney stones in the Democratic Republic of Congo (DRC) are lacking. To fill this gap, the present study was designed to determine the dietary habits of patients who followed for urolithiasis in the city of Kinshasa and to evaluate the association between dietary habits and the composition of the stones.

\section{Material and Methods}

\subsection{Study Design and Setting}

This was a dietary survey conducted from January 2017 to September 2019 among lithiasic patients attending 8 hospitals in the city of Kinshasa. In this case study, the sample size was not predetermined in its initial phase and the study focused on lithiasic patients for the most part easily accessible in hospitals that agreed to collaborate in this study. Thus, 85 patients had taken part in the study. Only the patients followed in these hospitals for urolithiasis who agreed to freely answer the questionnaire for this survey had taken part in this study.

\subsection{Dietary Survey}

The final report of the study on the identification and evaluation of the nutritional quality of food supplements in use in the DRC carried out by the non-governmental 
organization GAAD with funding and technical support from UNICEF [10] was used as a reference for the validation of this survey. Different foods commonly consumed in the DRC were categorized according to their composition: foods rich in animal proteins (beef, pork, goat meat, smoked meat, offal, chicken thighs, turkey rump, chicken, and others), foods high in salt (salted fish, cold meats, cans and others), foods rich in calcium (cow's milk, cheese, yogurt and others), foods high in sugar (sugary drinks, juices and other soda), foods rich in oxalate (peanuts, peanut feet, sorrel, spinach, eggs, chocolate and others) and various vegetables and fruits.

We then established a scale from 1 to 4 according to the frequency of consumption of these foods: occasional consumption of a food was rated 1, consumption once a week was rated 2, while consumption 2 to 3 times a week was rated 3 , and a daily consumption was rated 4 . Ratings 3 and 4 were categorized as heavy consumers of a given food.

We also evaluated daily water intake. This frequency was qualified as "a lot" when the patient took water several times during the day (quantity estimated at more than $1500 \mathrm{~mL} / \mathrm{d}$ ), "Not much" when the patient took water twice during the day (quantity estimated at 1000 to $1500 \mathrm{~mL} /$ day), finally "hardly" when there was only one dose during the day (quantity estimated at less than $1000 \mathrm{~mL}$ per day).

\subsection{Infrared Analysis of Stones and Study Parameters}

The different layers of stones were analyzed by Fourier transform infrared spectrophotometry (Vector 22 FT-IR spectrophotometer, Bruker Optics, Champssur-Marne, France) in absorbance mode by accumulation of 32 spectra between 4000 and $400 \mathrm{~cm}^{-1}$, with a resolution of $4 \mathrm{~cm}^{-1}$. Stones were classified according to their main component (chemical or crystalline body representing the large proportion in a stone).

Patient demographic and clinical data were obtained from medical records and during the medical appointment, including age, sex, place of residence, weight and height to calculate the body mass index (BMI), occupation, site of stones, existence of a urinary tract infection, comorbidities, and serum creatinine. Age was divided into 4 categories: $<20$ years, 20 - 39 years, $40-59$ years, and $\geq 60$ years. The profession was categorized in 3 groups: civil servant, liberal, and student/pupil and unemployed.

\subsection{Statistical Analysis}

Continuous variables were expressed as means and medians. Categorical variables were summarized into proportions. Differences in categorical variables between groups were assessed using Chi square test or the chi-square likelihood-ratio as appropriate. Differences in means were assessed by the student's $\mathrm{t}$ test. $p$ values less or equal to 0.05 were interpreted as statistically significant. Statistical analysis was performed using SPSS Statistics software version 22 (IBM, Armonk, USA). This study was approved by the ethics committee of the School 
of Public Health at the University of Kinshasa (approval number: ESP/CE/29/2020).

\section{Results}

A total of 85 lithiasis patients attending various hospitals in Kinshasa participated in this survey. Demographics are summarized in Table 1. The mean (SD) age of patients was 47.1 (14.0) years. Most participants were males $(63.5 \%, \mathrm{n}=$ 54). Sixty-four patients $(75.3 \%)$ had stones located in the upper urinary tract. Females had more upper tract stones compared to males $(90.3 \%$ vs. $66.7 \%, \mathrm{p}=$ $0.012)$. The vast majority of patients $(85 \%)$ were residents of Kinshasa.

While 6 (7.1\%) patients were undernourished, 46 (54.1\%) were overweight or obese. Just over a quarter of patients (25.9\%) had a urinary tract infection and Escherichia coli was the most frequently isolated bacteria. Twenty patients $(23.5 \%)$ had hypertension and 9 (10.6\%) had impaired renal function (Table 2 ).

Table 1. Sociodemographic parameters by the site of stones.

\begin{tabular}{|c|c|c|c|c|}
\hline \multirow[b]{2}{*}{ Variables } & \multirow{2}{*}{$\begin{array}{c}\text { All } \\
\mathrm{n}=85(\%)\end{array}$} & \multicolumn{2}{|c|}{ Site of stones } & \multirow[b]{2}{*}{$\mathrm{p}^{*}$} \\
\hline & & $\begin{array}{l}\text { Upper tract } \\
\mathrm{n}=64(\%)\end{array}$ & $\begin{array}{l}\text { Lower tract } \\
\mathrm{n}=21(\%)\end{array}$ & \\
\hline Age (years) & & & & 0.330 \\
\hline$\leq 19$ & $2(2.4)$ & $1(1.6)$ & $1(4.8)$ & \\
\hline $20-39$ & $24(28.2)$ & $17(26.6)$ & $7(33.3)$ & \\
\hline $40-59$ & $42(49.4)$ & $35(54.7)$ & $7(33.3)$ & \\
\hline$\geq 60$ & $17(20.0)$ & $11(17.2)$ & $6(28.6)$ & \\
\hline Sex & & & & 0.012 \\
\hline Females & $31(36.5)$ & $28(43.8)$ & $3(14.3)$ & \\
\hline Males & $54(63.5)$ & $36(56.2)$ & $18(85.7)$ & \\
\hline Residence & & & & 0.473 \\
\hline Kinshasa & $71(83.5)$ & $54(84.4)$ & $17(81.0)$ & \\
\hline Outside Kinshasa & $14(16.5)$ & $10(15.6)$ & $4(19.0)$ & \\
\hline Province of origin & & & & 0.030 \\
\hline Western & $36(42.4)$ & $32(50.0)$ & $4(19.0)$ & \\
\hline North & $15(17.6)$ & $9(14.1)$ & $6(28.6)$ & \\
\hline Center-South & $29(34.1)$ & $21(32.8)$ & $8(38.1)$ & \\
\hline Eastern & $5(5.9)$ & $2(3.1)$ & $3(14.3)$ & \\
\hline Profession & & & & 0.968 \\
\hline Unemployed & $33(38.8)$ & $24(37.5)$ & $9(42.9)$ & \\
\hline Official & $32(37.6)$ & $25(39.1)$ & $7(33.3)$ & \\
\hline Libéral & $12(14.1)$ & $9(14.1)$ & $3(14.3)$ & \\
\hline Student & $8(9.4)$ & $6(9.4)$ & $2(9.5)$ & \\
\hline
\end{tabular}

${ }^{\star}$ Pearson chi-square. 
Table 2. Clinical parameters according to the site of the stones.

\begin{tabular}{|c|c|c|c|c|}
\hline \multirow[b]{2}{*}{ Variables } & \multirow{2}{*}{$\begin{array}{c}\text { All } \\
\mathrm{n}=85(\%)\end{array}$} & \multicolumn{2}{|c|}{ Site of stones } & \multirow[b]{2}{*}{$\mathrm{p}^{*}$} \\
\hline & & $\begin{array}{l}\text { Upper tract } \\
\mathrm{n}=64(\%)\end{array}$ & $\begin{array}{c}\text { Lower tract } \\
\mathrm{n}=21(\%)\end{array}$ & \\
\hline BMI & & & & 0.682 \\
\hline Normal & $33(38.8)$ & $23(35.9)$ & $10(47.6)$ & \\
\hline Overweight & $29(34.1)$ & $23(35.9)$ & $6(28.6)$ & \\
\hline Obesity & $17(20.0)$ & $14(21.9)$ & $3(14.3)$ & \\
\hline Under nutrition & $6(7.1)$ & $4(6.2)$ & $2(9.5)$ & \\
\hline Urinary tract infection & & & & 0.624 \\
\hline Yes & $22(25.9)$ & $16(25.0)$ & $6(28.6)$ & \\
\hline E. coli & $10(11.8)$ & $8(12.5)$ & $2(9.5)$ & \\
\hline Staphylococcus & $5(5.9)$ & $4(6.2)$ & $1(4.8)$ & \\
\hline Citrobacter & $3(3.5)$ & $1(1.6)$ & $2(9.5)$ & \\
\hline Enterococcus & $2(2.4)$ & $1(1.6)$ & $1(4.8)$ & \\
\hline Klebsiella & $1(1.2)$ & $1(1.6)$ & $0(0.0)$ & \\
\hline Acinetobacter & $1(1.2)$ & $1(1.6)$ & $0(0.0)$ & \\
\hline No & $63(74.1)$ & $48(75.0)$ & $15(71.4)$ & \\
\hline Comorbidities & & & & 0.425 \\
\hline No & $22(25.9)$ & $17(26.6)$ & $5(23.8)$ & \\
\hline Arterial hyertension & $14(16.5)$ & $11(17.2)$ & $3(14.3)$ & \\
\hline Hypertension + diabetes & $5(5.9)$ & $4(6.2)$ & $1(4.8)$ & \\
\hline Diabetes & $3(3.5)$ & $2(3.1)$ & $1(4.8)$ & \\
\hline Yes & $63(74.1)$ & $47(73.4)$ & $16(76.2)$ & \\
\hline Renal function & & & & 0.293 \\
\hline Normal & $76(89.4)$ & $56(87.5)$ & $20(95.2)$ & \\
\hline Impaired & $9(10.6)$ & $8(12.5)$ & $1(4.8)$ & \\
\hline
\end{tabular}

*Pearson chi-square.

Most patients $(77.6 \%, \mathrm{n}=66)$ consumed vegetables and fruits. Other dietary habits found in these patients were excessive consumption of animal proteins $(62.4 \%, \mathrm{n}=53)$, heavy consumption of sugary drinks (58.8\%), consumption of foods rich in oxalate (58.8\%), high consumption of foods rich in calcium (40\%), and a salty foods (34.1\%). Most patients (68.2\%) drank less than $1500 \mathrm{~mL}$ of water in 24 hours.

Females consumed more salty foods than males (48.4\% women vs. $25.9 \%$ men, $\mathrm{p}=0.032$ ). Apart from the high-salt diet, we did not note any statistically significant differences between the eating habits and sex of the patients. Young adults consumed more sugary drinks than other age groups (83\% young adults vs. $59 \%$ adults and $23.5 \%$ people over $60, \mathrm{p}=0.002$ ) (Table 3 ). 
Table 3. Eating habits by sex and age.

\begin{tabular}{|c|c|c|c|c|c|c|c|c|c|}
\hline \multirow[b]{2}{*}{ Variables } & \multirow{2}{*}{$\begin{array}{c}\text { All } \\
\mathrm{n}=85(\%)\end{array}$} & \multicolumn{3}{|c|}{ Sexe } & \multicolumn{5}{|c|}{ Age groups (years) } \\
\hline & & $\begin{array}{c}\text { Woman } \\
\mathrm{n}=31(\%)\end{array}$ & $\begin{array}{c}\text { Man } \\
\mathrm{n}=54(\%)\end{array}$ & $\mathrm{p}$ & $\begin{array}{c}\leq 19 \\
\mathrm{n}=2(\%)\end{array}$ & $\begin{array}{c}20-39 \\
\mathrm{n}=24(\%)\end{array}$ & $\begin{array}{c}40-59 \\
\mathrm{n}=42(\%)\end{array}$ & $\begin{array}{c}\geq 60 \\
\mathrm{n}=17(\%)\end{array}$ & $\mathrm{p}^{*}$ \\
\hline Heavy cons of protein & & & & 0.439 & & & & & 0.166 \\
\hline Yes & $53(62.3)$ & $19(61.3)$ & $34(63.0)$ & & $1(50.0)$ & $18(75.0)$ & $27(64.3)$ & $7(41.2)$ & \\
\hline No & $32(37.7)$ & $12(38.7)$ & $20(37.0)$ & & $1(50.0)$ & $6(25.0)$ & $15(35.7)$ & $10(58.8)$ & \\
\hline Heavy cons. of salt & & & & 0.032 & & & & & 0.554 \\
\hline Yes & $29(34.1)$ & $15(48.4)$ & $14(25.9)$ & & $1(50.0)$ & $7(29.2)$ & $17(40.5)$ & $4(23.5)$ & \\
\hline No & $56(65.9)$ & $16(51.6)$ & $40(74.1)$ & & $1(50.0)$ & $17(60.8)$ & $25(59.5)$ & $13(66.5)$ & \\
\hline Heavy cons. Calcium & & & & 0.520 & & & & & 0.072 \\
\hline Yes & $34(40.0)$ & $12(38.7)$ & $22(40.7)$ & & $2(100.0)$ & $9(37.5)$ & $13(30.9)$ & $10(58.8)$ & \\
\hline No & $51(60.0)$ & $19(61.3)$ & $32(59.3)$ & & $0(0.0)$ & $15(62.5)$ & $29(69.1)$ & $7(31.2)$ & \\
\hline heavy cons. of Sugar & & & & 0.367 & & & & & 0.002 \\
\hline Yes & $50(58.8)$ & $17(54.8)$ & $33(61.1)$ & & $1(50.0)$ & $20(83.3)$ & $25(59.5)$ & $4(23.5)$ & \\
\hline No & $35(41.2)$ & $14(45.2)$ & $21(38.9)$ & & $1(50.0)$ & $4(16.7)$ & $17(40.5)$ & $13(76.5)$ & \\
\hline Heavy cons. Oxalate & & & & 0.453 & & & & & 0.223 \\
\hline Yes & $50(58.8)$ & $19(61.3)$ & $31(57.4)$ & & $2(100.0)$ & $11(45.8)$ & $28(66.7)$ & $9(52.9)$ & \\
\hline No & $35(41.2)$ & $12(38.7)$ & $23(42.6)$ & & $0(0,0)$ & $13(54.2)$ & $14(33.3)$ & $8(47.1)$ & \\
\hline Heavy cons. of vegetables & & & & 0.197 & & & & & 0.271 \\
\hline Yes & $66(77.6)$ & $22(71,0)$ & $44(81.5)$ & & $2(100.0)$ & $20(83.3)$ & $29(69.0)$ & $15(88.2)$ & \\
\hline No & $19(22.4)$ & $9(29.0)$ & $10(18.5)$ & & $0(0.0)$ & $4(16.7)$ & $13(31.0)$ & $2(11.8)$ & \\
\hline Water & & & & 0.307 & & & & & 0.809 \\
\hline A lot & $27(31.8)$ & $7(22.6)$ & $20(37.0)$ & & $1(50.0)$ & $7(29.2)$ & $13(30.9)$ & $6(35.3)$ & \\
\hline No a lot & $32(37.6)$ & $12(38.7)$ & $20(37.0)$ & & $1(50.0)$ & $8(33.3)$ & $15(35.7)$ & $8(47.1)$ & \\
\hline Almost not & $26(30.6)$ & $12(38.7)$ & $14(25.9)$ & & $0(0.0)$ & $9(37.5)$ & $14(33.4)$ & $3(17.6)$ & \\
\hline
\end{tabular}

${ }^{\star}$ Pearson chi-square, the $\mathrm{p}$ correspond to the distribution of eating habits according to sex and age groups of patients.

Patients residing in the provinces of the DRC had a saltier diet $(64.3 \%$ outside Kinshasa vs. 28.2 Kinshasa, $\mathrm{p}=0.012$ ) than those residing in the city of Kinshasa. People from the western and northern provinces consumed more sugary drinks than those from other DRC provinces $(66.7 \%$ West and $80 \%$ North vs. 41.4\% Center-South and 40\% East, $\mathrm{p}=0.041$ ) (Table 4).

Only the stones of 61 out of the 85 patients who took part in this dietary survey were extracted during our study period and analyzed at the TENON hospital (APHP, Paris, France).

The whewellite majority in the stones of 45 patients (or 73.8\%) was the largest majority body. The other major bodies identified were carbapatite (in $6.5 \%$ of cases), weddellite $(6.5 \%)$, struvite $(4.9 \%)$, ammonium urate $(4.9 \%)$ and 1 anhydrous uric acid (4.9\%). 
Table 4. Eating habits according to place of residence and province of origin.

\begin{tabular}{|c|c|c|c|c|c|c|c|c|c|}
\hline \multirow[b]{2}{*}{ Variables } & \multirow{2}{*}{$\begin{array}{c}\text { All } \\
\mathrm{n}=85 \\
(\%)\end{array}$} & \multicolumn{2}{|c|}{ Home } & \multirow[b]{2}{*}{$\mathrm{p}$} & \multicolumn{4}{|c|}{ Provinces of origin } & \multirow[b]{2}{*}{$\mathrm{p}$} \\
\hline & & $\begin{array}{c}\text { Kinshasa } \\
\mathrm{n}=71(\%)\end{array}$ & $\begin{array}{c}\text { Hors Kinshasa } \\
\mathrm{n}=14(\%)\end{array}$ & & $\begin{array}{c}\text { Western } \\
\mathrm{n}=36(\%)\end{array}$ & $\begin{array}{c}\text { North } \\
\mathrm{n}=15(\%)\end{array}$ & $\begin{array}{l}\text { Center-south } \\
\mathrm{n}=29(\%)\end{array}$ & $\begin{array}{c}\text { Eastern } \\
\mathrm{n}=5(\%)\end{array}$ & \\
\hline Heavy cons. of protéin & & & & 0.561 & & & & & 0.316 \\
\hline Yes & $53(62.4)$ & $44(62.0)$ & $9(64.3)$ & & $21(58.3)$ & $12(80.0)$ & $16(55.2)$ & $4(80.0)$ & \\
\hline No & $32(37.6)$ & $27(38.0)$ & $5(35.7)$ & & $15(41.7)$ & $3(20.0)$ & $13(44.8)$ & $1(20.0)$ & \\
\hline Heavy Consumer of salt & & & & 0.012 & & & & & 0.591 \\
\hline Yes & $29(34.1)$ & $20(28.2)$ & $9(64.3)$ & & $15(41.7)$ & $5(33.3)$ & $8(27.6)$ & $1(20.0)$ & \\
\hline No & $56(65.9)$ & $51(71.8)$ & $5(35.7)$ & & $21(58.3)$ & $10(66.7)$ & $21(72.4)$ & $4(80.0)$ & \\
\hline Heavy consumer calcium & & & & 0.259 & & & & & 0.502 \\
\hline Yes & $34(40.0)$ & $30(42.3)$ & $4(28.6)$ & & $15(41.7)$ & $8(53.3)$ & $10(34.5)$ & $1(20.0)$ & \\
\hline No & $51(60.0)$ & $41(57.7)$ & $10(71.4)$ & & $21(58.3)$ & $7(46.7)$ & $19(65.5)$ & $4(80.0)$ & \\
\hline Heavy consumer of sugar & & & & 0.557 & & & & & $0.041^{\star}$ \\
\hline Yes & $50(58.8)$ & $42(59.2)$ & $8(57.1)$ & & $24(66.7)$ & $12(80.0)$ & $12(41.4)$ & $2(40.0)$ & \\
\hline No & $35(41.2)$ & $29(40.8)$ & $6(42.9)$ & & $12(33.3)$ & $3(20.0)$ & $17(58.6)$ & $3(60.0)$ & \\
\hline Heavy consumer of oxalate & & & & 0.442 & & & & & 0.574 \\
\hline Yes & $50(58.8)$ & $41(57.7)$ & $9(64.3)$ & & $24(66.7)$ & $8(53.3)$ & $16(55.2)$ & $2(40.0)$ & \\
\hline No & $35(41.2)$ & $30(42.3)$ & $5(35.7)$ & & $12(33.3)$ & $7(46.7)$ & $13(44.8)$ & $3(60.0)$ & \\
\hline Heavy cons of vegetables & & & & 0.053 & & & & & 0.449 \\
\hline Yes & $66(77.6)$ & $58(81.7)$ & $8(57.1)$ & & $26(72.2)$ & $11(73.3)$ & $24(82.8)$ & $5(100.0)$ & \\
\hline No & $19(22.4)$ & $13(18.3)$ & $6(42.9)$ & & $10(27.8)$ & $4(26.7)$ & $5(17.2)$ & $0(0.0)$ & \\
\hline Hydrant & & & & 0.898 & & & & & 0.629 \\
\hline A lot & $27(31.8)$ & $23(32.4)$ & $4(28.6)$ & & $13(36.1)$ & $5(33.3)$ & $8(27.6)$ & $1(20.0)$ & \\
\hline No a lot & $32(37.6)$ & $27(38.0)$ & $5(35.7)$ & & $15(41.7)$ & $3(20.0)$ & $12(41.4)$ & $2(40.0)$ & \\
\hline Almost not & $26(30.6)$ & $21(29.6)$ & $5(35.7)$ & & $8(22.2)$ & $7(46.7)$ & $9(31.0)$ & $2(40.0)$ & \\
\hline
\end{tabular}

${ }^{*}$ Likelihood chi-square, $\mathrm{p}$ correspond to the distribution of eating habits according to the residence and province of origin of the patients.

Anhydrous uric acid stones were completely associated with a high BMI (overweight) and $50 \%$ of carbapatite stones were associated with under nutrition ( $\mathrm{p}=$ 0.025). No statistically significant difference was noted between the distribution of urinary tract infection and majority stone bodies.

Males with a diet rich in oxalate had more calcium oxalate stones (64.3\%) compared to other major bodies (carbapatite, struvite and ammonium urate urate) $(\mathrm{p}=0.041)$ (Table 5).

\section{Discussion}

\section{Eating Habits and Chemical Composition of Stones}

In this study, vegetable consumption was the most predominant diet. The other dietary habits found in these lithiasis patients included high consumptions of 
Table 5. Majority bodies based on BMI, urinary tract infection and oxalate consumption in men.

\begin{tabular}{|c|c|c|c|c|c|c|c|}
\hline \multirow[b]{2}{*}{ Variables } & \multirow{2}{*}{$\begin{array}{c}\text { All } \\
\mathrm{n}=61 \\
(\%)\end{array}$} & \multicolumn{5}{|c|}{ Corps majoritaires regroupés } & \multirow[b]{2}{*}{$\mathrm{p}^{*}$} \\
\hline & & $\begin{array}{c}\text { Oxalate } \\
\text { de calcium } \\
\mathrm{n}=49(\%)\end{array}$ & $\begin{array}{c}\mathrm{CA} \\
\mathrm{n}=4(\%)\end{array}$ & $\begin{array}{c}\text { PAM } \\
n=3(\%)\end{array}$ & $\begin{array}{c}\text { AU0 } \\
\mathrm{n}=2(\%)\end{array}$ & $\begin{array}{c}\text { UrAm } \\
\mathrm{n}=3(\%)\end{array}$ & \\
\hline BMI & & & & & & & 0.025 \\
\hline Normal & $22(36.1)$ & $19(38.8)$ & $0(0.0)$ & $2(66.7)$ & $0(0.0)$ & $1(33.3)$ & \\
\hline Overweight & $22(36.1)$ & $17(34.7)$ & $0(0.0)$ & $1(33.3)$ & $2(100.0)$ & $2(66.7)$ & \\
\hline Obesity & $13(21.3)$ & $11(22.4)$ & $2(50.0)$ & $0(0.0)$ & $0(0.0)$ & $0(0.0)$ & \\
\hline Under nutrition & $4(6.6)$ & $2(4.1)$ & $2(50.0)$ & $0(0.0)$ & $0(0.0)$ & $0(0.0)$ & \\
\hline Urinary tract infection & & & & & & & 0.928 \\
\hline Yes & $16(26.2)$ & $13(26.5)$ & $1(25.0)$ & $1(33.3)$ & $0(0.0)$ & $1(33.3)$ & \\
\hline No & $45(73.8)$ & $36(73.5)$ & $3(75.0)$ & $2(66.7)$ & $2(100.0)$ & $2(66.7)$ & \\
\hline & $\mathrm{n}=36(\%)$ & $\mathrm{n}=28(\%)$ & $\mathrm{n}=1(\%)$ & $\mathrm{n}=2(\%)$ & $\mathrm{n}=2(\%)$ & $\mathrm{n}=3(\%)$ & \\
\hline Heavy cons. oxalate & & & & & & & 0.041 \\
\hline Yes & $20(55.6)$ & $18(64.3)$ & $0(0.0)$ & $0(0.0)$ & $2(100.0)$ & $0(0.0)$ & \\
\hline No & $16(44.4)$ & $10(35.7)$ & $1(100.0)$ & $2(100.0)$ & $0(0.0)$ & $3(100.0)$ & \\
\hline
\end{tabular}

*Pearson chi-square. CA: carbapatite, PAM: struvite, AU0: anhydrous uric acid and UrAm: ammonium urate.

animal proteins, consumptions of foods rich in oxalate, refined sugars, calcium, and consumptions of foods high in salt. Also, men with a diet high in oxalate had more calcium oxalate stones compared to other main stones.

Most of patients in this study (77.6\%) had a diet rich in vegetables and fruits. Several studies have demonstrated the protective role of a diet rich in vegetables and fruits [11] [12]. Likewise, a Dietary Approaches to Stop Hypertension (DASH) diet, rich in fruits, vegetables, whole grains, and low-fat dairy products, has been shown to significantly reduce the risk of kidney stone formation [13]. However, it is worth mentioning that the protective effect of a diet rich in vegetables and fruits is only observed in people who rarely consume them [12]. Indeed, Meschi et al. [12] found that urinary citrate excretion was significantly reduced and calcium excretion was significantly increased after a two-week diet of vegetables in a normal population [12]. Furthermore, Daudon et al. [14] revealed that a vegetable diet is often rich in oxalic acid and poor in calcium, which would promote hyperoxaluria and the formation of calcium oxalate stones observed in developing countries. In this study, whewellite (73.8\%) was the most frequent component and less than half of patients (40\%) consumed foods rich in calcium. Thus, the need to examine the oxalate content in various green leaves and vegetables regularly consumed in the DRC.

In this study, $58.8 \%$ of patients had a diet rich in oxalate and a statistically significant association was found between a diet rich in oxalate and calcium oxalate stones in men. Higher consumptions of oxalate increase the risk of stone forma- 
tion [15]. Oxalate, a terminal acid in metabolism whose primary route of excretion is the kidney, binds to calcium to form calcium oxalate which is an important lithogenic complex [9] [16]. Three potential sources of oxalate intake are known: foods rich in oxalate (represents $10 \%$ to $20 \%$ urinary oxalate) [9] [16], hyperoxaluria may be secondary to intestinal malabsorption [16] [17] [18] [19] and hepatic oxalate synthesis which depends on lean body mass (represents $80 \%$ to $90 \%$ of oxalate). However, a diet very low in oxalate can reduce urinary oxalate excretion by half [9] and only $100-1000 \mathrm{mg}$ of free oxalate which is absorbed per day [9] [14].

Besides higher consumptions of vegetables, we also found that $62.4 \%$ of patients had a diet rich in animal proteins and $58.8 \%$ consumed refined sugars contained in juices and other soft drinks. Ferraro et al. [20] found that higher consumption of sugary drinks was one of the modifiable risk factors associated with urinary stones. There is also evidence that sugary and carbonated drinks increase the risk of urinary stone formation [21]. Zhuo et al. [11] reported that animal protein intake was significantly associated with the occurrence of urolithiasis. Short-term restriction of animal protein significantly reduces the excretion of calcium, phosphate, hydroxyproline, uric acid and oxalate and increases the excretion of citrate in the urine, reducing the risk of stone formation [22]. Therefore, patients with recurrent calcium oxalate urate stones should decrease consumptions of animal proteins and avoid foods high in purines.

It is known that calciuria is an important determinant of calcium lithogenicity because hypercalciuria is found in $30 \%$ to $60 \%$ of lithiasis patients. Calciuria is influenced by nutritional factors such as excessive salt, calcium, and proteins intake [9] [14] [16] [23] [24]. In this study higher intake of salt, calcium and proteins were found in $34.1 \%, 40 \%$, and $62.4 \%$ of cases, respectively.

Milk, dairy products, and drinking water are the main sources of dietary calcium [9] [16]. Digestive absorption of calcium represents $20 \%$ of the amount ingested, or $5 \mathrm{mmoL} / \mathrm{d}(200 \mathrm{mg}$ ), and the kidney is the only way out of calcium. Any excess sodium intake in food leads to increased urinary calcium excretion. It is also known that the consumption of animal proteins is associated with the increased incidence of calcium urolithiasis. The multifactorial effects of excess animal proteins include: lowering of urinary $\mathrm{pH}$, increased excretion of calcium, uric acid, oxalate and a decrease in citrate excretion. [14] [25] [26] [27] [28]. Thus, sodium intake must be maintained around 6 and $7 \mathrm{~g} / \mathrm{d}$; whereas protein intakes should be normalized to $1 \mathrm{~g} / \mathrm{kg} /$ day in adults [29] [30].

This dietary survey revealed that $68.2 \%$ of patients drank less than $1500 \mathrm{~mL}$ of water per 24 hours. High fluid intake has been shown to increase urine volume, reduce the concentration of calcium oxalate in urine, and reduce the risk of stone formation by $50 \%$ and the recurrence rate from $60 \%$ to $80 \%$ [31] [32]. Indeed, Zhuo et al. [11] demonstrated that fluid intake was significantly associated with the occurrence of urolithiasis. We believe that lower water intake in our study is due, at least partially, by limited access to clean drinking water. Water intake should be harmoniously distributed throughout the day and adjusted ac- 
cording to the fluid losses. This could help prevent urolithiasis and reduce the frequency of recurrence [16] [31]. Remember that there are three categories of water; prepackaged natural mineral waters, prepackaged spring waters and water for public distribution (tap water), rainwater and well water; the latter being generally very low in calcium. Mineral and spring waters are the only ones that can take advantage of properties favorable to health, benefiting from an original nature and purity, coming from underground water free from any pollution, stable in their composition [9].

Finally, the small sample size of this hospital series is a limiting factor that must be taken into account in interpreting these results. But, beyond this possible limit, this study made it possible for the first time to describe the eating habits of lithic patients in the DRC.

\section{Conclusion}

In this study, high consumptions of vegetables and low water intake were linked to the formation of calcium oxalate monohydrate stones. More data are needed to confirm these findings.

\section{Acknowledgements}

The authors sincerely thank the Department of Functional Explorations of the Tenon Hospital in Paris, the staff of the Urology Department of the University Clinics of Kinshasa, as well as all the partner hospitals and doctors who agreed to collaborate with us in the context of this study.

\section{Conflicts of Interest}

No conflict of interest has been declared by the authors.

\section{Authors' Contributions}

PD, DM designed, collected, interpreted, wrote and corrected the manuscript. EM, AN analyzed the data, read and corrected the article. JRM, ML and ES read and edited the article, MD and PD carried out the morpho-constitutional analysis of stones, and revised the manuscript, APM, SL, MD and JPH supervised, interpreted and edited the article. All authors have read and approved the final version of the article.

\section{References}

[1] Shadman, A. and Bastani, B. (2017) Kidney Calculi: Pathophysiology and as a Systemic Disorder. Iranian Journal of Kidney Diseases, 11, 180-191.

[2] Ziemba, J.B. and Matlaga, B.R. (2017) Epidemiology and Economics of Nephrolithiasis. Investigative and Clinical Urology, 58, 299-306.

https://doi.org/10.4111/icu.2017.58.5.299

[3] Shin, S., Srivastava, A., Alli, N.A. and Bandyopadhyay, B.C. (2018) Confounding Risk Factors and Preventative Measures Driving Nephrolithiasis Global Makeup. World Journal of Nephrology, 7, 129-142. https://doi.org/10.5527/wjn.v7.i7.129 
[4] Dissayabutra, T., Kalpongkul, N., Rattanaphan, J., Boonla, C., Srisa-art, M., Ungjaroenwathana, W., et al. (2018) Urinary Stone Risk Factors in the Descendants of Patients with Kidney Stone Disease. Pediatric Nephrology, 33, 1173-1181. https://doi.org/10.1007/s00467-018-3927-1

[5] Sorensen, M.D., Hsi, R.S., Chi, T., Shara, N., Wactawski-Wende, J., Kahn, A.J., et al. (2014) Dietary Intake of Fiber, Fruit and Vegetables Decreases the Risk of Incident Kidney Stones in Women: A Women's Health Initiative Report. Journal of Urology, 192, 1694-1699. https://doi.org/10.1016/j.juro.2014.05.086

[6] Mirzaei, K., Aghamir, S.M.K., Modaresi, S.S. and Yekaninejad, M.S. (2017) Major Dietary Patterns and Kidney Stone Formation among Iranian Men. Journal of $\mathrm{Nu}^{-}$ tritional Science and Healthy Diet, 3, 11-17.

[7] Fakhoury, M.Q., Gordon, B., Shorter, B., Renson, A., Borofsky, M.S., Cohn, M.R., et al. (2018) Perceptions of Dietary Factors Promoting and Preventing Nephrolithiasis: A Cross-Sectional Survey. World Journal of Urology, 37, 1723-1731. https://doi.org/10.1007/s00345-018-2562-6

[8] Icer, M.A. and Gezmen-Karadag, M. (2018) Determination of the Effect of Nutritional Status on PRAL Level in Patients with Nephrolithiasis. Gümüşhane University Journal of Health Sciences, 7, 1-9.

[9] Traxer, O., Lechevallier, E. and Saussine, C. (2008) Diététique et lithiase rénale. Le rôle de l'urologue. Progrès en Urologie, 18, 857-862.

https://doi.org/10.1016/j.purol.2008.09.041

[10] (2019) Etude sur le recensement et l'évaluation de la qualité nutritionnelle des aliments de complément en République Démocratique du Congo. Rapport Final, Octobre 2019.

[11] Zhuo, D., Li, M., Cheng, L., Zhang, J., Huang, H. and Yao, Y. (2019) A Study of Diet and Lifestyle and the Risk of Urolithiasis in 1,519 Patients in Southern China. Medical Science Monitor, 25, 4217-4224. https://doi.org/10.12659/MSM.916703

[12] Meschi, T., Maggiore, U., Fiaccadori, E., Schianchi, T., Bosi, S., Adorni, G., et al. (2004) The Effect of Fruits and Vegetables on Urinary Stone Risk Factors. Kidney International, 66, 2402-2410. https://doi.org/10.1111/j.1523-1755.2004.66029.x

[13] Taylor, E.N., Fung, T.T. and Curhan, G.C. (2009) DASH-Style Diet Associates with Reduced Risk for Kidney Stones. Journal of the American Society of Nephrology, 20, 2253-2259. https://doi.org/10.1681/ASN.2009030276

[14] Daudon, M. (2005) Épidémiologie actuelle de la lithiase rénale en France. Annales d urologie, 39, 209-231. https://doi.org/10.1016/j.anuro.2005.09.007

[15] Gasinska, A. and Gajewska, D. (2007) Tea and Coffee as the Main Sources of Oxalate in Diets of Patients with Kidney Oxalate Stones. Roczniki Państwowego Zakładu Higieny, 58, 61-67.

[16] Ernandez, T., Chopard, C.S., Bonny, O., Iselin, C., Martin, P.-Y. and Jaeger, P. (2013) Approche pratique de la lithiase rénale: Duo entre généralistes et spécialistes. Revue Médicale Suisse, 9, 456-461.

[17] Sakhaee, K., Maalouf, N.M. and Sinnott, B. (2012) Kidney Stones 2012: Pathogenesis, Diagnosis, and Management. Journal of Clinical Endocrinology \& Metabolism, 97, 1847-1860. https://doi.org/10.1210/jc.2011-3492

[18] Dobbins, J.W. and Binder, H.J. (1976) Effect of Bile Salts and Fatty Acids on the Colonic Absorption of Oxalate. Gastroenterology, 70, 1096-1100. https://doi.org/10.1016/S0016-5085(76)80318-6

[19] Jaeger, P. and Robertson, W.G. (2004) Role of Dietary Intake and Intestinal Absorp- 
tion of Oxalate in Calcium Stone Formation. Nephron Physiology, 98, 64-71. https://doi.org/10.1159/000080266

[20] Ferraro, P.M., Taylor, N.E., Gambaro, G. and Curhan, G.C. (2017) Dietary and Lifestyle Risk Factors Associated with Incident Kidney Stones in Men and Women. Journal of Urology, 198, 858-863. https://doi.org/10.1016/j.juro.2017.03.124

[21] Ferraro, P.M., Taylor, E.N., Gambaro, G. and Curhan, G.C. (2013) Soda and Other Beverages and the Risk of Kidney Stones. Clinical Journal of the American Society of Nephrology, 8, 1389-1395. https://doi.org/10.2215/CJN.11661112

[22] Heilberg, I.P. and Goldfarb, D.S. (2013) Optimum Nutrition for Kidney Stone Disease. Advances in Chronic Kidney Disease, 20, 165-174.

https://doi.org/10.1053/j.ackd.2012.12.001

[23] Romero, V., Akpinar, H. and Assimos, D.G. (2010) Kidney Stones: A Global Picture of Prevalence, Incidence, and Associated Risk Factors. Reviews in Urology, 12, e86-e96.

[24] Worcester, E.M. and Coe, F.L. (2010) Clinical Practice. Calcium Kidney Stones. New England Journal of Medicine, 363, 954-963.

https://doi.org/10.1056/NEJMcp1001011

[25] Robertson, W.G. and Peacock, M. (1982) The Pattern of Urinary Stone Disease in Leeds and in the United Kingdom in Relation to Animal Protein Intake during the Period 1960-1980. Urologia Internationalis, 37, 394-399. https://doi.org/10.1159/000280845

[26] Anderson, D.A. (1969) Historical and Geographical Differences in the Pattern of Incidence of Urinary Stones Considered in Relation to Possible Aetiological Factors. In: Hodgkinson, A. and Nordin, B.E., Eds., Renal Stone Research Symposium, Churchill Livingstone, London, 7-31.

[27] Robertson, W.G., Peacock, M., Heyburn, P.J., Speed, R. and Hanes, F. (1979) The Role of Affluence and Diet in the Genesis of Calcium-Containing Stones. In: Vahlensieck, W. and Gasser, G., Eds., Pathogenese und Klinik der Harnsteine VI, Vol. 11, Steinkopff, Heidelberg, 5-14. https://doi.org/10.1007/978-3-642-47063-9_2

[28] Nguyen, Q.V., Kalin, A., DRouve, U., Casez, J.P. and Jaeger, P. (2001) Sensitivity to Meat Protein Intake and Hyperoxaluria in Idiopathic Calcium Stone Formers. Kidney International, 59, 2273-2281. https://doi.org/10.1046/j.1523-1755.2001.00744.x

[29] Lemaire, M. (2018) La lithiase rénale: Comment éviter la récidive? Louvain Médical, 137, 279-276.

[30] Taylor, E.N. and Curhan, G.C. (2008) Determinants of 24-Hour Urinary Oxalate Excretion. Clinical Journal of the American Society of Nephrology, 3, 1453-1460. https://doi.org/10.2215/CJN.01410308

[31] Borghi, L., Meschi, T., Amato, F., Briganti, A., Novarini, A. and Giannini, A. (1996) Urinary Volume, Water and Recurrences in Idiopathic Calcium Nephrolithiasis: A 5-Year Randomized Prospective Study. Journal of Urology, 155, 839-843. https://doi.org/10.1016/S0022-5347(01)66321-3

[32] Cheungpasitporn, W., Rossetti, S., Friend, K., Erickson, S.B. and Lieske, J.C. (2016) Treatment Effect, adherence, and Safety of High Fluid Intake for the Prevention of Incident and Recurrent Kidney Stones: A Systematic Review and Meta-Analysis. Journal of Nephrology, 29, 211-219. https://doi.org/10.1007/s40620-015-0210-4 


\section{DATA COLLECTION SHEET: DIETARY SURVEY OF LITHIASIC PATIENTS IN KINSHASA.}

NAME:

$\begin{array}{lll}\text { Gender: M F } & \text { Date of birth: } & \text { Nationality: } \\ \text { Address: } & \text { Weight: } & \text { Size: } \\ \text { Province of origin: } & \text { Profession: } & \end{array}$

LOCATION OF THE CALCULATION (at the time of its urological treatment):

Kidney/calyx:

upper $\square$ middle $\square$ lower $\square$ bassinet $\square$ bladder $\square$

Ureter:

high $\square$ medium $\square$ low $\square$ coralliform: complete $\square$ incomplete $\square$ Pyelocalicial junction $\square$ Pyelo-ureter $\square$ Ureterovesical $\square$ Other: Obstructive lithiasis: Yes

Kidney destroyed: Yes No $\square$

Side: left $\square$ right $\square \quad$ Number of calculations: ELIMINATION METHOD:

Spontaneous $\square$ endoscopic $\square$ surgical $\square$ PCNL $\square$ Lithotripsy-endocorporeal $\square$ extracorporeal $\square$ rigid ureteroscopy $\square$ flexible $\square$ other:

Disposal date: / /

DISCOVERY CIRCUMSTANCE(S):

C.N. $\square$ Hematuria $\square$ Urinary tract infection

A.S.P.

Lower back pain $\square$ other:

Is this a 1st stone $\square$ of a recurrence $\square$ on the same side $\square$ on the opposite side

Other in situ stones: Yes No $\square$ If Yes: location:

Malformation Yes No $\square$ If Yes: type

Urinary tract infection: Yes $\square$ No

Recurrent: Yes $\square$ No $\square$ Germ (s):

PRESUMED ETIOLOGY OF STONE:

PERSONAL HISTORY:

Diabetes $\square$ hypertension $\square$ other: Yes $\square$ No $\square$

If yes, which ones:

REGULAR TREATMENTS: Yes No

By Diamox $^{\star}-$ Cycloteriam $^{\star}-$ Prestole $^{\star}-$ Calcium + Vitamin D - Beta-blockers

- Lipid lowering agents - Rocéphine ${ }^{\star}-$ Praxilene $^{\star}-$ Others (specify):

DIET

Food preference: 1 . Occasionally 2. Once a week 3.2 - 3 times a week 4. Every day

Animal protein (beef, pork, thigh and others): $\quad \begin{array}{lllll}1 & 2 & 3 & 4\end{array}$

Salt (salted fish, cold meats, soda and others): $\quad \begin{array}{lllll}1 & 2 & 3 & 4\end{array}$

Calcium (milk, cheese, yogurt and others): $\quad \begin{array}{lllll}1 & 2 & 3 & 4\end{array}$ 
Sugar (sweet drink, juice and other soda)

$\begin{array}{llll}1 & 2 & 3 & 4 \\ 1 & 2 & 3 & 4 \\ 1 & 2 & 3 & 4\end{array}$

$\begin{array}{lllll}\text { Oxalate (chocolate, peanut, sorrel, and others): } & 1 & 2 & 3 & 4 \\ \text { Vegetables and fruits: } & 1 & 2 & 3 & 4\end{array}$

Frequency of water intake per day: A lot: several times/day. Not a lot: once or twice a day. Almost not: less than once a day
A lot
Not a lot
Almost not
Value balance

Urea:

Creatinine:

Blood sugar: 